This is the post print version of the article

Nissilä, Paula: Young people at a revivalist summer gathering:

Rituals, liminality, and emotions. Social Compass 65(2), 278-294

https://doi.org/10.1177/0037768618768437

Copyright (c) 2018 The Author.

Reprinted by permission of SAGE Publications.

\title{
Young people at a revivalist summer gathering: rituals,
}

\section{liminality, and emotions}

\begin{abstract}
This article examines the religiosity of young people at a summer gathering of a

Christian revivalist movement. Studies on religious mass events as social phenomena, as well as research on youth participation, are still quite few. The open-air summer gatherings of the traditional Finnish revivalist movements operating within the national Evangelical Lutheran Church of Finland attract masses of people from all generations simultaneously as the church itself sustains losses at the attendee rates of the more institutional collective practices. This article seeks to answer why this event is appealing for a group of active young people by investigating their visitor experiences and the meanings attached. It perceives the event as transient arena for expressing, negotiating, and reviving religious meanings. Drawing on interviews, participant observation, and narratives, this qualitative case study seeks to illustrate current religiosity and, in general, to contribute to the comprehension of collective religiousness in people's somewhat individualized and private religious lives.
\end{abstract}




\section{Keywords}

religious festivals, religious mass events, revivalist movements, young people

\section{Résumé}

Cet article examine la religiosité des jeunes ayant participé à un rassemblement estivale d'un mouvement évangélique en Finlande. Les études sur les événements religieux de masse en tant que phénomène social et sur la participation des jeunes restent encore limitées. Les rassemblements estivaux et en pleine air de mouvements évangéliques traditionnels finlandais opérant au sein de l'Église évangélique luthérienne de Finlande attirent des individus de toutes les générations, alors que l'Eglise elle-même subit une perte au niveau du nombre de participants aux pratiques collectives plus institutionnelles. Cet article explore la raison pour laquelle cet événement estival a attiré un certain groupe de jeunes actifs en analysant leurs expériences et la valeur qu'ils y attachent. Ils perçoivent l'événement comme un champ transitoire où il devient possible d'exprimer, négocier et raviver les valeurs religieuses. En s'appuyant sur des entretiens, des observations participantes et des récits, cette étude de cas qualitative cherche à explorer la religiosité actuelle et, en général, à contribuer à comprendre la signification de la religiosité collective dans la vie religieuse privée et individualisée. 


\section{Mots-clés}

festivités religieuses, rassemblements religieux de masse, mouvements évangéliques, jeunesse

\section{Introduction}

The recent religious trend in Europe has been a decline in institutional affiliation and public participation. In Finland, as elsewhere in the protestant Nordic countries, this has become evident through the dwindling membership rate of the national church over the past ten years. Similarly, people spend their leisure time less often by participating in services and other congregation events organized by the Evangelical Lutheran Church of Finland. The attendance rate for the main services has decreased by $24 \%$ over the last ten years (2005-2015; Statistical Yearbook of the Evangelical Lutheran Church of

Finland, 2014; Sakasti.evl.fi - Statistics). Likewise, in Europe, local religious traditions are increasingly challenged by global changes and immigration, and the situation is being shaped through growing religious diversity and the emergence of new forms of spirituality (Davie, 2012).

Still, according to data from the International Social Survey Programme (ISSP), in 2011, 39\% of Finnish people saw themselves as religious and $40 \%$ prayed at least once a month. In addition, $40 \%$ of the Finnish respondents reported that they 
connect with God without churches or religious services. Put simply, the practice of religion is increasingly shifting outside the public arena but people still have interest in spirituality and religious beliefs. Individualized religious behaviour has been described, for instance, as 'believing without belonging' (Davie, 1994). The situation in the Nordic countries can also be described as 'believing in belonging'. The still relatively high $73 \%$ (2015) share of church members in Finland - approximately four million people - has been considered as an expression of the specific Nordic emphasis on belonging to national churches (e.g. Niemelä, 2015). Studies discussing the role of the Nordic state churches have underlined the debate over collectivity and individualization (e.g. Bäckström, 2014; Ketola, et al., 2014).

As a deviation in individualization trend, the large-scale open-air summer gatherings of the traditional Finnish revivalist movements and organizations within the national church have succeeded in remaining full of vitality. The still vital role of these movements, their socio-political role in history, and continuance under the church organization are distinctive features for Finland, even compared to the other Nordic countries (Church Research Institute, 2013: 172-177). The movements date mostly back to the late 1800th century and origin from the Lutheran Reformation and German pietism emphasizing the individual experiences of faith and grass roots religious life. Despite the variable plural characteristics of the current revivalist movements, according to the 2004 Church Monitor survey, every tenth Finn belonged to a revivalist 
movement, and an equal share stated that their thinking was influenced by the movements, despite not actually belonging to any of them (Church Research Institute, 2013: 174-175). Approximately 140,000 Finnish people - nearly 3\% of the country's population - attended the summer celebrations of the revivalist movements in the summer of 2012. This article focuses on the meanings that one of the largest of these revivalist celebrations, the summer gathering of the Awakening Movement, a moderate and plural community both socially and theologically (Salomäki, 2010: 44, 375-8), creates and maintains for a group of young people. Why do these young people find this collective form of religiosity appealing?

The summer gatherings are the social celebrations of a religious community. They highlight the strengths and social relationships of the community in a certain context. This article examines the gathering from the view of the social sciences as defined by Andrews and Leopold (2013: 53): 'Events are stages in which different performances consisting of social interaction, processes, and behaviours are taking place, directed by underlying functions of the event context'. The distinctive characteristic of a festival as an event is perceived to be its public celebratory nature (Getz, 2012: 51-3), also referred to as festive sociability (Costa, 2001).

Religious youth events as social phenomena are not yet widely explored. Regardless, not only the events operate as negotiation arenas of traditions, but the adolescence has its specific role in the spiritual development of an individual and its 
processes interact greatly with other life events and identity building (Benson and Roehlkepartain, 2008). Further, it has been argued that the role of the religion in identity construction relies significantly on the connection between the young and the community or other youths' religious experiences (King, 2003).

Even so, there are some attempts to widen the sociological understanding about religious events and young visitors' experiences, precisely approaching them as a collective form of religiosity attracting masses of people. The international Catholic World Youth Day, one of the world's largest youth gatherings with millions of participants, has been investigated on the visitors' motives to attend (Rymarz, 2007), the event's impact on religious practices (Singleton, 2011), and volunteering (Webber, 2012). The WYD visitors are called pilgrims and the event viewed as modern pilgrimage (Norman and Johnson, 2011). Indeed, the religious tourism literature highlights that distinctive feature considering pilgrimage is that it connects the religious participation to the journey as a ritual by itself (e.g. Blackwell, 2007). Rymarz (2007) describes the WYD as a deviation in the privatization of religious expressions of Catholic youth and in the youth's overall drift from the mainstream churches. The visitors cherish high hopes for experiencing the faith 'alive' among others in joyful and international atmosphere. Singleton (2011) reveals this affirming influence of momentspecific experience on religious commitment through the evidence of the increase on Mass attendance post-WYD, especially concerning youth with high pre-existing 
religiosity, and specifically through intense communality and the emotional part of the program. In addition, the youths proudly manifest their participation in religious rituals at the WYD, not merely just vanish in the crowd (Singleton, 2011).

Based on her studies in mainly Catholic Poland, Baraniecka-Olszewska (2014) perceives these religious crowds as a relevant actor in the Church. According to her, the Catholic mass events outside the Catholic Church order are expressions of autonomy and individuality. Besides, she highlights that many non-religious persons take part in these events, that way binding themselves to the religious frame. This same is revealed in the studies of Abby Day $(2010,2013)$. She argues that the belief appears as a way of integrating oneself into relationships, also regarding the non-religious persons taking part in religious performances.

Don Handelman (1997) has emphasized the rituals becoming more spectacles being direct visual and vocal presentations operating as mirrors, whereas the rituals manipulate cultural categories in more hidden way. Some recent studies have demonstrated this spectacle side of the religious rituals, like studies on multidimensional Dutch EO Youth Day (Roeland, 2012) and Toronto's Jesus in the City parade (Ingalls, 2012). However, the participants in religious crowds are not merely spectators, they might even contradict to the role set for them by the event organizers although the acceptance of being part of the community and acting as religious crowd is 
indispensable, and the participant experiences have to be similar enough (BaranieckaOlszewska, 2014).

The moment-specific character of the religious events and spectacles illustrated, one can consider Zygmunt Bauman's (2000) ‘cloakroom communities’ of liquid modernity, where people arrive at a short-term spectacle leaving the coats of various daily lives in the cloakroom, as the momentary emotional intensiveness creates the illusion of unity. Furthermore, with its temporary and traditional elements, the collection of individuals at the religious gathering has the characteristics of a 'wispy community': a concept encompassing the gathering's transient, entertaining, and sociable features, yet retaining the expectations towards identity construction and networking as well as the demands for attention-in-the-moment and interactional loyalty (Fine and den Scott, 2011). Further, one can highlight Victor Turner's (e.g. 1982: 47-8) concept of 'spontaneous communitas' denoting anti-structural and immediate communal interaction.

Francois Gauthier (2015) has argued that the embodied social forms of current religion emphasize non-institutional events where both dimensions - the intimate circles and the mass meetings - are present, and supporting both experiences of belonging and individual expression. Referring to the multi-spiritual Burning Man festival, Gauthier (2015: 266) states 'It is the mass gathering that provides the canvas and the opportunity for more intimate circles to form'. Similarly, in their work on young 
people's religious beliefs and participation in the mainly Catholic Poland, Mandes and Rogaczewska (2013: 271) draw attention to religious carnivals as 'the best examples of young people's longing for a type of belief, which is not necessarily doctrinal or propositional, but expressed physically, which is democratic, shared with others, nonorthodox, and performed on special occasions (thus not bound to daily routine)'. This institutional versus short-term commitment is explored also in the studies of Quebecois religiously marginal communities in otherwise catholic area (Meintel, 2014). The threeday event of this study attracts on average 30,000 visitors every summer, even though the actual share of paying members within the movement' organization is only 5,600 (as of 2015). This indicates that the institutional membership of the movement is not the basis of participation. In this article, the context of the religious festival represents a transient arena for expressing, negotiating, and reviving religious meanings and belonging, and the focus is on the event context and negotiation work.

\section{Data and methods}

This study represents a micro-sociological approach to the experienced world by exploring people and religion in action here-and-now, 'not just what people say but what they actually do and experience' (Collins, 2010: 17). As festival theorist Donald Getz (2010: 21) argues in his broad review of festival studies, the need for hermeneutical festival studies on experiences and meanings is commonly well 
recognized. The research in this article is based on interviews, narratives, and observation notes. Informants' anonymity was assured, also concerning the gender and the residences of the informants due to the exclusiveness of the community under study.

A total of 23 interviews were conducted at the 2013 gathering in Haapajärvi, town of 7,500 people in central Finland. The interviews were semistructured in order to further the participants' personal interpretations of their experiences. The questions concentrated on the event experience in terms of the personal event history, meanings relating to event participation and the movement behind it, and general visitor satisfaction and experiences relating to the atmosphere, activities, and arrangements. Likewise, other personal summer event experiences and possible connections to other revivalist movements were discussed. The interviews were one-to-one, except for one pair interview, and the interviewees were approached spontaneously. The interviews ranged in length from four to 18 minutes. The age range was $14-18$ years, and 19 of the interviewees $(n=24)$ were female and five were male.

Additionally, 62 post-festival narratives were gathered during the following autumn. These narratives came from young people aged 14-17 years, although nine of the respondents did not state their age. The most narratives were collected using a premade form during a 15-minute voluntary period at a camp session. The free-form writing was instructed with a title of the celebration 2013. The task was organized by the movement's youth workers. Additionally, a smaller portion came as a 
reply to a request for narratives which was linked to Facebook groups. The narratives represented mainly open question -type writing and varied from a couple of sentences to longer stories with schemes.

The volunteering was a defining feature of the study group. The portion of $2 / 3$ of all interviewees mentioned participation and even more the youth accommodation which often followed the volunteering. Half of the narratives referred directly to the volunteer work. The overall number of youth volunteers was approximately 190, with 160 staying in youth accommodation. Considering the data, it is notable that the group of young people in this study represents a restricted portion of the festival crowd. Young people attending with their families or not taking part in the voluntary work, or not staying in the youth accommodation, were not part of the interviewees except for one brief interview which was included as it contributed to the analysis. The research design rests on investigating the group of young people involved with the activities of the youth work of the movement.

The specific age group of 14-18 was selected linked to the activities and data collected on site. It became quickly obvious that most of the youths hanging around in pairs or groups were part of the active, volunteering portion. Then, the narratives were collected within the movement's youth work which is targeted to this same age range. 
To support the analysis, observation was performed during three-day event. The observation concentrated on the crowd, the young people, and the activities in the celebration area, the accommodation (a school), and nearby localities. In addition, informal discussions with the employees and youth workers took place. Photography supported the observation notes. The event can be freely accessed by everyone. Permission to participate as a researcher in the event was guaranteed beforehand by the organizers.

The ethical issues of this study related to the age and developmental phase of the informants, and the sensitivity of religion as a study object. Thus, the guidelines of the Finnish advisory board on research integrity were followed, especially as interviewing without guardians the youths under the self-determination age of 15 years although those youths were minority in the data $(n=8)$, and most of them answered the open-ended narrative suggestion.

In analysis, the data was approached in its entirety, proceeding to more specific themes relating to the research questions on collectiveness in the transient festival context. All interviews, narratives, and field notes were analysed in detail with atlas.ti program, and codes round themes, positions, attitudes, and discourses were developed. These codes were attached to code families and these to larger meaning categories. The analysis adhered to grounded theory, as it included working 
interactively and systematically among the data and theories, aiming to understand the phenomena (Thornberg and Charmaz, 2012: 41-42).

\section{Youth, religion, and the transient space of negotiating meaning}

The open air gathering of the Awakening Movement is organized at a different site every year, both in localities traditionally impacted by the movement and in more virgin territories, for example, 2016 celebration occurred in Vantaa, one of Finland's most urban areas. The celebration, established in 1893, is a symbol of the communality of the movement, and it attracts people from many generations. The event is organized by the movement's organization, the local parish of the Evangelical Lutheran Church, and the local municipality. Besides the voluntary work that enables the event, the essential rituals encompass several revival services reminiscent of traditional revival meetings at home, with alternating short speeches and hymns sung without instrumental accompaniment and suggested spontaneously by the crowd. For many attendees, the monotonic continuity and feeling of longing in the revival tunes - the Hymns of Zion create the emotional atmosphere of the gathering. Like prayers, they reflect the spiritual emphasis of the movement on the idea of human insufficiency and on the God's mercy as a comfort in everyday life. Noteworthy, the charismatic evangelization is quite uncharacteristic for the current Awakening Movement. 
Overall, the event represents time to meet relatives and other people in the context of a spiritual programme. When enquiring about the main reason for attending the celebration, the majority of the young interviewees mentioned their friends. Many also highlighted meeting new acquaintances, and the overall communal atmosphere and shared activities, such as volunteer work. Direct references to the event's religious content - such as to the Awakening Movement as an ideology, the traditional revival services, or God - were made only in a minority of the answers. The emphasis of social aspects and communal solidarity as uppermost motives applies also to the narratives' views although the narratives were freely written and the most important thing was not asked directly. Thus, as also mentioned on interviews, the Hymns of Zion and singing were mentioned among important things. More relating directly to the faith content, out of all 62 narratives, two named spirituality as an important element, three mentioned the significance of the service speeches and one the receiving of the communion.

A youth programme has been included in the general programme since the end of the 1960s. In 2013, the youth programme featured, for instance, a night café with open stage, night chanting, and concerts. The days of the volunteering young people in this study were also delineated with bagging and selling traditional sweets. In addition, the central framework for the young people was the youth accommodation in the local school. 
The celebration is considerably self-sufficient and operates on a voluntary basis. Food is served in the area and there is joint accommodation in local schools in addition to the tent and trailer areas organized. On the site, it appeared that the compact self-reliance furthered the sense of community. The transient characteristics of the gathering and the communitas represented itself also in rituals during the closing day. The event finishes with final revival service, which comprises the collective kneeling of the whole crowd during prayer, followed by the traditional shared pew-lifting ritual that marks the end of the event. The participants gather the benches in the celebration field by joint effort.

The meanings relating to the construction of the community of young people at the gathering emerged through three dimensions: separation from the mundane, liminality, and emotional experiences relating to the programme. These dimensions highlight the event-based features of the religious rituals.

The data clearly reveals that for the young people at the revival rally, the event represents a way of breaking away from daily circles, a different world. This separation from everyday life, escape and seeking, is linked to the tourism behaviour (Iso-Ahola, 1982). Additionally, the significance of the separation from the mundane context as a social practice is a central characteristic of the special collective ritual event defined in structural ritualization theories (Knottnerus, 2014). The event also released the youths from the mundane rules set by others. The respondents valued the freedom to 
choose for themselves what to do and with whom to do it - or to just do nothing other than hang around. The youths also chose suitable voluntary work shifts themselves. This context-related freedom also highlighted the separation from the other generations in the meanings attached to the festival.

Travelling to the event site, with its elements of reunion, appeared to be part of the celebration experience, and elements of pilgrimage could be identified in the data. The young people who travelled by train reunited with friends at stations along the journey. If travelling to the locality with their family by car or other method, the youths often headed to the local station to welcome incoming friends. This retells the features of the Catholic World Youth Day as a modern pilgrimage and that way the tourism aspects (e.g. Blackwell, 2007). It was interesting to note that many of the young people considered the long distance to the event location to be irrelevant, if not positive.

It is noteworthy that some informants reflected on their presence at the celebration positively compared to their experiences as outsiders among their local friends and other people in their hometown. The respondents also highlighted that at the event they can be anonymous and released from the pressures of domestic life. When enquiring about the best thing at the gathering, one interviewee responded, retelling Bauman's ideas on the unity of the 'cloakroom community':

Well, probably all the new people. [Place removed] is quite a small place so then... kind of everybody knows everybody, there are these groups. Here there are new people from 
everywhere in Finland, so then you can kind of make a fresh start and so... No one has any prejudices when there are not so many from the same place. (Interviewee, 15 years)

Besides, the young attendees described that it was very easy to make new friends.

Furthermore, festivals are occasions to reverse the social order of everyday life through rites (Falassi, 1987: 4). At the revival celebration this culminated in avoiding sleeping which strengthened the youth community. Hence, the creation of symbolic chaos related to the social logic of festivals was clearly present. Additionally, the youths were mainly accompanied in the local school; school's reverse role compared to the weekday context emphasized the distinctive nature of the event. The youth obtained free accommodation if they participated in preparatory voluntary work, i.e. bagging the traditional sweets sold at the event. Staying up through the night was a ritual and this significant norm appeared so strong that going to sleep was experienced as excluding oneself from the group:

The nights are the best time for young people at the gathering. There aren't any schedules to follow. On the other hand, you might easily feel like an outsider unless you're hanging around in some group for the whole time. If you go to sleep, you feel like you're doing something wrong because then you are probably missing something really nice for which the celebration will be remembered later by the young people. Although wanting to be awake the next day, I mean also mentally, you feel guilty for turning in. (Narrative)

However, the accommodation applied the regulations imposed by the organizers, but with flexibility compared to the other activities of movement's youth work. The facilities were supervised through the night time, but the young people were allowed to 
stay up, and to come and go as they pleased in the neighbourhood. As the nearby service station opened early in the morning, some made their way towards it.

Returning home was often regarded as re-entering the routines and the calm of everyday life. In short, young people were returning from the religious celebration to quieten down: 'after the celebration, it's always lovely to go back home to sleep and calm down' (narrative). This marks the moment when the other transient reality of the here-and-now ceases, and describes the experience of effervescence, which took its toll. The possible shared family ride home was also a clear descent back into routines. Thus, the disorder emerged as a festival characteristic.

One of the profoundest advocates for reflecting on temporary separation from mundane structures is the classic ritual theorist Victor Turner. According to Turner $(1969,1982)$ the celebrative rituals encompass the elements of sacred, play, and communitas, which emphasizes the autonomy of the temporary community compared with the structures of the institutions in the surrounding society. Turner (1969) links the very nature of the festival to two operational dimensions: the group solidarity experienced in a liminal phase of transition (Van Gennep, [1909]1960) and the temporary context of communitas originating from it. The data revealed the significance of the celebration as an initiation and the liminal dimensions among the youth group. The transitions were from childhood to adolescence and from the time spent with the family to young people's own rallies, encompassing autonomy and independence. In 
relation to socialization, the dimensions of initiation related to the phase of life (age), the group of young people, and the independence from parents and older generations at the event and within the movement. The transitions in spiritual events and Turner's theories are also discussed, for instance, in a study of the multicultural and multispiritual Burning Man festival (Gilmore, 2006). Overall, a common experience was a sense of being a novice, such as if being 'a first-timer' at the rally when independently staying in the youth accommodation and participating in voluntary work. The personal history of celebration with parents or relatives might have run over years or even a decade, but the current experience was experienced as totally different, as the first real celebration. This distinction was meaningful.

The main theme that arose from the data was the essential role of the youth group as the creator of the atmosphere and shared experiences. The peer group created a liminal phase in the continuum of being a celebration visitor. The earlier social space of traditions when attending with one's family as a child loomed on one horizon, and possibly carrying on the tradition as an adult visitor, loomed on the other. The feeling of standing on the ambiguous threshold, in 'social limbo' (Turner), as a space where the regulations of the past or the future are not totally valid, occurs in the following narrative:

This gathering was the umpteenth for me. I've been around the gatherings since I was small. This gathering was, however, special because for the first time I stayed in youth accommodation. The experience was really nice, it was nice to experience the gathering 
in a slightly different way. I was free to walk around the celebration area and Haapajärvi, and to sit in the particular revival service I wanted. Anyway, I missed sitting in the service with granny and grandpa or with the family a little bit and listening how men and women talked about this and that. That's why I had to get to sit in the ending service next to granny and grandpa. (Narrative, 16 years)

In relation to first-timers, the data encompassed several young people whom the confirmation camp led to the gathering and to the other activities of the movement. Confirmation is one of the most significant church-based rituals in Finland. It usually occurs during the year of fifteenth birthday and it guarantees, for example, the right to organize a church wedding in the future. Some $81 \%$ of Finnish adolescents aged 14-15 years were confirmed in 2015 (Sakasti.evl.fi - Statistics), which was more than the actual member share of the Church (73\%). Confirmation requires classes, which are in most cases completed in the form of a confirmation camp. As many of the young people in this study performed the confirmation classes at the movement's camp, they represent a $17 \%$ share of those who were confirmed outside their home congregation based on residence. Participation in the celebration was part of the continuum starting from confirmation at Aholansaari, a salient site for the movement. For many informants, the period spent at Aholansaari confirmation camp represents a strong shift into the youth group, regardless of whether it could also be perceived as a shift in personal spirituality. The time at Aholansaari also occurred as a tradition, but the personal experience of the celebration among other young people was distinguished from the earlier generations. 
According to Turner and Turner (1982), liminality is a process that includes characteristics like shared joy, spontaneity, and sacredness without status hierarchies. The communitas gains strength through shared activities and emotional experiences. However, as described earlier, homecoming was often experienced as returning to calmness and a contentment with the rules of everyday life among the studied youth. From this perspective, the transformation effect included in Turner's theory of liminality and communitas remains vague, and it might even indicate that the event is a liminoid period that emphasizes the individuality and temporary character of the escape from mundane structures (Turner, 1982).

The youth volunteer time was mostly occupied with bagging and selling the traditional sweets, körtti pastilles (körtti denoting an adherent of the movement), mainly from carts as circulating the celebration area. The volunteering was reflected as an obvious part of the event and as fun but the effort and duller side were also acknowledged (like waking up early). The selling of the sweets and them as a symbol of communal solidarity of the movement and as uniting element within the generations, was reflected, as one interviewee states when talking about being a körtti:

If you say like körttipastilli (körtti pastille), everybody starts smiling and not asking what that is. So it's a place where one clearly belongs. (Interviewee, 17 years)

Alongside the experiences of membership, a successful ritual is perceived to produce emotional energy, a resource carrying on through interaction chains, and likewise temporary emotions act as links for it (Collins, 2004). This idea rests on Émile 
Durkheim's concept of collective effervescence. The earlier analysis of breaking the mundane order by staying up late has the features of collective turmoil through exhaustion. Although the revivalist gathering has its more permanent elements due to the history of the community and its rituals, the expectations of transient gatherings 'wispy communities' - to generate fun, memories, stories and separation from mundane life were present (Fine \& van den Scott, 2011). In the studies of festival motives, the programme is found to correlate specifically with the emotional values of the attendees (Lee, Lee \& Choi, 2011). Indeed, the Catholic World Youth Day's success draws also strongly on expectations of joy and excitement, which differ significantly from everyday life experiences in local religious circles in school or parishes (Rymarz, 2007).

The revival celebration of 2013 offered a targeted programme for young people, such as a night café with open stage, night chanting, and concerts. This was valued significantly in the meanings of young people. Though the premises of the night café filled up with young people in the company of supervisors and security personnel, the atmosphere was intimate. The young people were sitting on the tables or on the floor watching the peer band playing, and some were playing board games. The space was dark with disco lights. Earlier, outside the café some participants played Frisbee. While chatting with the cleaners of the night café premises the morning after, I heard satisfied comments that luckily some places were kept clean by the visitors. 
As 2013 was the fortieth anniversary of the organization's youth work, many concerts, including one for a record release, were performed under the theme. The respondents regarded these activities very positively. Additionally, the majority of the respondents participate in voluntary work by doing sales work. As an additional activity, they produced noisy sales songs. Besides, the youth accommodation was a significant context for the young people. During the spare time, the premises were filled with music, games, and youths hanging around. The voluntary work was also considered just to be fun, and not that much thought was given to its philosophical basis.

Once, when asking some of the interviewees if the event could be viewed as comparable to a secular festival, the youths expressed the differences in meanings relating to attributes like noise and 'running wild all night' at secular festivals. However, as observed, these elements were also present at this event. On the last day, the organizers informed me that some young people attempted to access the roof of the building during the night. As the night supervisor and one interviewee informed me, staying up could also be perceived as avoiding the hour of parting to be confronted on Sunday, the final day. Staying up and, on the other hand, dozing during the daytime, playing, and selling candy in a playful spirit can be perceived as signs of effervescence. Group cohesion related to the emotional experiences concerning the programme and hanging around at the gathering. The atmosphere was described as 
relaxed and amusing and attached with meanings of fun and joy. The randomness of eating and sleeping created an 'adventurous feeling'. The experiences of frivolity in the frameworks of traditions and the separation from the other generations were emphasized:

Well, maybe the name "revival celebration" sounds a little bit, kind of... frightening, so that people would sit here amid the grannies, singing hymns, like... To me it has never meant anything like that, maybe when I was very small... But anyway, now at least this is like just free hanging around. It's all made quite easy for us. (Interviewee, 17 years)

One interviewee commented on the comparison between the atmosphere in the celebration area and in the youth accommodation: 'I rather think that the atmosphere is where the other young people are'. The relation between the religious crowd and more intimate circles was reflected as some of the informants described that, for instance, the nights and the time outside the volunteering shifts were pleasant because you can withdraw to smaller, cosier groups.

The numerous revival services as the main part of the gathering programme divided the young peoples. The services have their roots in pietistic conventicles and in the small-scale devotional services in home surroundings. It is the most significant symbol for the entire movement. Many of the informants showed a lack of interest in the revival services. A common view amongst informants was that there were just other, more enjoyable things to occupy their time with. The service speeches and their contents remained quite unmentioned in the discussions and narratives. 
Certainly, some of the young people attended the services and sang with enthusiasm; some even commented that they looked forward to the chanting, but even often then, the overall attitude can be encapsulated in this interview extract:

So that we're always with [removed], almost always, when it's possible to get to a revival service, we're going although it's a bit of a grannies' fuss hehhe. Yes, and everybody is like not going so much to the services, but we always like them. When we just have even the smallest time, we'll go singing then. (interviewee, 15 years)

Overall, it appeared that when the young people attended the revival service, showing up around the area was the main purpose and was deemed sufficient. The young people were using their phones, laying on the ground or chatting around the edges of the celebration area. Entering into the service just by hanging around represented belonging, not merely to the young generation but to the community of all the generations. At the same time, they delivered their generation-bound promise in maintaining traditions. Some mentions on the closing revival services with the collective kneeling as especially important might be interpreted as in the end, after spending the days with peers, one wanted to join the traditions shared with generations.

Nevertheless, the youth programme selection offered night chanting, where the young people sang the same traditional hymns in their peer group. It was popular. Even as a researcher, I felt emotionally impressed while sitting on a church pew listening to the youth's monotonic, strong rhythmic a cappella singing, pausing expectantly from time to time. The rhythm has been described as rolling. Many knew 
the lyrics by heart. Some of the young people sang with their eyes closed, whether this was due to the atmosphere or tiredness from staying up was unclear. Overall, the ongoing negotiation of meaning over the traditional ritual of the revival service appeared in the youth's attitudes toward them. The traditional hymns and collective singing were experienced closely, but the multi-generational formal revival services at the gathering could be skipped, despite the recommendation to participate included in the instructions for the youth work.

Relating to religious experience, Durkheim's collective effervescence produces group solidarity. Durkheim ([1912]1976) regarded this to intensify religious experience. Admittedly, intensive collective emotions appeared among the young people at the gathering. It is also stated in interaction ritual theories (see Collins, 2004) that the collectively produced long-term 'emotional energy' orients the individual's future interaction rituals, this shown in the studies on Mass attendance after WYD (Singleton, 2011). Drawing on her studies on young people, Abby Day $(2010,2013)$ has investigated belief as a way of integrating oneself into relationships in order to build a desirable identity. Day has also pointed out that in her studies, non-religious persons may take part in religious performance just because they wish to build and share a certain identity with others. In this study, this was demonstrated for instance in a narrative stating that although the respondent is an atheist, the gathering was still an essential part of the summer. In general, there was no special emphasis on the 
strengthening of the personal faith as attending the event. The comments of the substance of the movement were mainly connected with family traditions, the revival services, communal atmosphere, social activities and youth work. The more spiritual dimensions seemed difficult for the young people to define. The characteristics of tolerance, 'being as one is' and seeking were mentioned which supports the interpretation that the youths were not experiencing much pressures for religious commitment.

\section{Conclusion}

This article has viewed a religious event as a transient space for negotiations on religion and traditions by exploring the social logic of the three-day summer celebration of the Awakening Movement rooted on the ideas about religiosity as expressing social identity (Day). In order to understand what makes this gathering tick, it revealed the meanings that young people attach to the Christian summer gathering in their experiences and activities. The gathering of the Awakening Movement is a religious ritual that succeeds every year in producing emotional energy in a multi-generational group of people. It is a social success story even compared to many secular festivals. The analysis revealed that for the young people, the gathering creates ritualistic frameworks for the separation of the mundane, liminal group experiences, and emotional unity. The elements of escaping daily life by entering the liminal stage of the youth group in the gathering and the 
collective emotional effervescence arising from the shared accommodation and activities tie the young people to the group.

As also in case of the World Youth Day, the separation from the home localities was essential and socially based. However, in this study the sacred destination' of the pilgrimage appeared to be the peer group and the repetition of the former (like confirmation) experiences with the friends. The event operated as the biggest opportunity to meet all the acquaintances. The religious framework with its rituals made the event unique but the religious content slipped into the background. Compared with the WYD where the Catholic youths empowered from the presence of the same believing, highly religious elite peers, the youths in this study drew from the togetherness and shared rituals not minding that much about the cohesion of the beliefs.

The belonging to the peer group creates its own norms. This emerged in the data through the meanings of being an outsider when not staying up or even not entering the gathering at all. In the data, there were also young people who were firsttimers or did not possess relational ties to the movement before its confirmation camp which then led them to the gathering. The role of siblings' or cousins' preceding attendance at the confirmation camp of the movement was also articulated as an influencing factor. Apparently, the mechanisms of group identification also promote dimensions that are not necessarily intense religious experiences but rather secular experiences and based on collective physical activities, like the shared volunteering 
tasks. Abby Day (2011) considers belief to be a performance of belonging - people are 'believing in belonging' - and uses the concept of 'performative belief' as the belief originates in shared activities and repetitive rituals. The peer group solidarity also appeared through the ease of making new acquaintances which partly made the atmosphere more democratic.

Additionally, young people valued their freedom and marked their distinctive position relating to the traditional revival services in the main programme that way reflecting the claim for autonomy shown in previous studies (e.g. Mandes and Rogaczewska, 2013; Baraniecka-Olszewska, 2014). Many were not that interested in participating in the services due to the fact that there were just so many funnier things to do. Additionally, when entering the arena of the multi-generational revival service, simply being present as part of the crowd was regarded as a sufficient commitment. But, nevertheless, they were there. The shared activities in the youth peer group, 'thebreathing-of-the-same-air-presence' during the multi-generational occasions, as well as the participation in the tradition of volunteering, could be interpreted as performative belief. In addition, the young people underlined the uniqueness of the personal celebration experience in the meaning construction, compared to the previous possible ones attending with the family.

The transient character of the event acted as an element in youths' festival experience. The intense emotional elements (fun, joy, exhaustion, even longing relating 
to the inevitable departure as the event closes) rising from the shared activities and physical closeness here-and-now were relevant to young people. The carnival-type aspects were a salient part of the experience. There was an urge to take part into the activities even during the night in order to not miss anything uniting the group afterwards. In brief, the marks of the collective effervescence (Durkheim), developed by Randall Collins (2004) as a term of emotional energy, were obvious at the gathering. Additionally, the liminal elements relating to the transitions in age phase and visitor status promoted temporary communitas and social cohesion in the youth group. The essential question is whether the collective activities, emotions, and group ties create a more intense religious experience or whether the experiences are simultaneously - or more or less - secular. Based on this study, one could ask if they even could be separated. Similarly, we may ask at what level these experiences tie the young people to the traditions shared by the generations, and how much they interrelate with spiritual or doctrinal contents. Studies of the sociological aspects of the World Youth Day have noted that through shared travel and participation, openly believing and belonging, the visitors create a temporary, belief-strengthening community for pre-existing catholic faith (e.g. Rymarz, 2007; Singleton, 2011). This aspect of belief affirmation of the young people in this study would need more research and elaboration.

From a cultural-political view, by attaching new meanings, traditional cultural events, such as this event also is, can be seen to adapt to change and the 
challenges of both tradition and modernization, not just to celebrate tradition (CrespiVallbona and Richards, 2007). Young people at this gathering cherished their own separate traditions at the event in a democratic and autonomous way. The organization of the movement has also made the decision to supply this kind of space for young people via the special youth programme, thus generating the possibility to produce a sub-culture within the event. The emotional energy arising from the interaction likely benefits the movement. Nevertheless, this study indicates that the intense, shared group experiences in the context of the transient event play a significant role in the success of the Awakening gathering for these young people. The context of the short-term event represents a not-so-institutional, intimate religious practice under the wide umbrella of the institution of Evangelical Lutheran Church and its services and congregational activities, and the reference group of young people represents a spontaneous community within the institutional frames of the traditional revivalist movement. To conclude, the belonging to this religious community appeared even as this event was transient, or perhaps because of that. The organization offers leisure activities, fun and atmosphere to the young people, as well as traditions, quite unchanged and yet autonomously to be chosen or not.

Concentrating on the transient event characteristics can be seen simultaneously as an advantage and a limitation of this study. It reveals the power of the not-so-institutional, moment-based characteristics of the religious experience in current 
times. However, the more long-term implications and faith-related aspects would require a different research focus.

\section{Funding}

This work was supported by the Kone Foundation.

\section{References}

Andrews H and Leopold T (2013) Events and the social sciences. Abingdon, Oxon:

Routledge.

Baraniecka-Olszewska K (2014) Role of the religious crowd in the mass Catholic events: The Passion Play and Nativity Play in Warsaw. Anthropological notebooks 20(2): 27-43.

Bauman Z (2000) Liquid modernity. Cambridge: Polity.

Benson PL and Roehlkepartain EC (2008) Spiritual development: A mission priority in youth development. In: E. C. Roehlkepartain EC and Benson PL and Hong KL (eds) New directions for youth development: Special issue on spiritual development. San Francisco: Jossey-Bass, pp.13-28.

Blackwell R (2007) Motivations for religious tourism, pilgrimage, festivals and events. In: Raj R and Morpeth ND (eds) Religious Tourism and Pilgrimage Festivals Management: An International Perspective. Wallingford: CABI Pub., pp.35-47. 
Bäckstrom A (2014) Religion in the Nordic Countries: Between Private and Public. Journal of Contemporary Religion 29(1): 61-74.

Church Research Institute (2013) Community, Participation, and Faith: Contemporary Challenges of the Evangelical Lutheran Church of Finland. Publication of the Church Research Institute, 62. Tampere: Church Research institute.

Collins R (2004) Interaction ritual chains. Princeton University Press.

Collins R (2010) The Micro-sociology of Religion: Religious Practices, Collective and Individual (ARDA Guiding Paper Series). State College, PA: The Association of Religion Data Archives at The Pennsylvania State University. Available at: http://www.thearda.com/rrh/papers/guidingpapers.asp (accessed 25 May 2016). Costa X (2001) Festivity: Traditional and Modern Forms of Sociability. Social Compass 48(4): 541-548.

Crespi-Vallbona M and Richards G (2007) The meaning of cultural festivals. International Journal of Cultural Policy 13(1): 103-122.

Davie G (1994) Religion in Britain since 1945. Believing without Belonging. Oxford: Blackwell.

Davie G (2012) Thinking Sociologically About Religion: Implications for Faith Communities. Review of Religious Research 54(3): 273-289.

Day A (2010) Propositions and performativity: Relocating belief to the social. Culture and religion 11(1): 9-30. 
Day A (2011) Believing in belonging. Belief and Social Identity in the Modern World. Oxford: Oxford University Press.

Day A (2013) Varieties of Belief over Time: Reflections from Longitudinal Study of Youth and Belief. Journal of Contemporary Religion 28(2): 277-293.

Durkheim E (1976) [1912] The elementary forms of the religious life. London: Allen \& Unwin.

Falassi A (1987) Festival: Definition and Morphology. In: Falassi A (ed) Time out of time: Essays on the festival. Albuquerque: University of New Mexico Press, pp. 1-10. Fine GA and van den Scott LJ (2011) Wispy communities: Transient Gatherings and Imagined Micro-Communities. American Behavioral Scientist 55(10): 1319-1335. Gauthier F (2014) Intimate circles and mass meetings. The social forms of eventstructured religion in the era of globalized markets and hyper-mediatization. Social compass 61(2): 261-271.

Getz D (2010) The Nature and Scope of Festival Studies. International Journal of Event Management Research 5(1): 1-47.

Getz D (2012) Event Studies: Theory, Research and Policy for Planned Events. 2. ed. Oxford: Elsevier.

Gilmore L (2006) Desert Pilgrimage: Liminality, Transformation, and the Other at the Burning Man Festival. In: Swatos WH (ed) On the Road to Being There: Studies in 
Pilgrimage and Tourism in Late Modernity. Boston: Brill Academic Publishers, pp.125-158.

Handelman D (1997) Rituals/Spectacles. International Social Science Journal 49(153): 423-436 [Special Issue, Anthropology: Issues and Perspectives. 1: Transgressing Old Boundaries].

Ingalls MM (2012) Singing praise in the streets: Performing Canadian Christianity through public worship in Toronto's Jesus in the City parade. Culture and Religion: An Interdisciplinary Journal 13(3): 337-359.

Iso-Ahola SE (1982) Toward a social psychological theory of tourism motivation: a rejoinder. Annals of tourism research 9(2): 256-262.

Ketola K and Martikainen T and Salomäki H (2014) New communities of worship: Continuities and mutations among religious organizations in Finland. Social compass 61(2): 153-171.

King PE (2003) Religion and Identity: the Role of Ideological, Social and Spiritual contexts. Applied Development Science 7(3): 197-204.

Knottnerus DJ (2014) Religion, ritual, and collective emotion. In: von Scheve C and Salmela S (eds) Collective emotions: Perspectives from Psychology, Philosophy, and Sociology. Oxford University Press, pp.312-325.

Lee JS \& Lee CK \& Choi Y (2011) Examining the role of emotional and functional values in festival evaluation. Journal of Travel Research 50(6): 685-696. 
Mandes S and Rogaczewska M (2013) “I don’t reject the Catholic Church - the Catholic Church rejects me": How Twenty- and Thirty-somethings in Poland Reevaluate their Religion. Journal of Contemporary Religion 28(2): 259-276.

Meintel D (2014). Religious collectivities in the era of individualization. Social compass 61(2): 195-206.

Niemelä K (2015) ‘No longer believing in belonging': A longitudinal study of Finnish Generation Y from confirmation experience to Church-leaving. Social compass 62(2): $172-186$.

Norman A and Johnson M (2011) World Youth Day: The Creation of a Modern Pilgrimage Event for Evangelical Intent. Journal of Contemporary Religion 26(3): 37185.

Roeland J, Klaver M and Van Der Meulen M et al. (2012) "Can we dance in this place?": Body Practices and Forms of Embodiment in Four Decades of Dutch Evangelical Youth Events. Journal of Contemporary Religion 27(2): 241-256. Rymarz R (2007) Who goes to World Youth Day? Some data on under-18 Australian participants. Journal of Beliefs \& Values 28(1): 33-43.

Sakasti - Service for the employees and actors in the Evangelical Lutheran Church of Finland. Statistics. Available at: www.sakasti.evl.fi (accessed 15 May 2016). 
Salomäki H (2010) The commitment to revivalist movements [Herätysliikkeisiin sitoutuminen ja osallistuminen] PhD Thesis, University of Jyväskylä. Publication of the Church Research Institute 113. Tampere: Church Research institute.

Singleton A (2011) The impact of World Youth Day on religious practice. Journal of Beliefs \& Values 32(1): 57-68.

Statistical Yearbook of the Evangelical Lutheran Church of Finland (2014) [Kirkon tilastollinen vuosikirja 2014]. Available at:

http://sakasti.evl.fi/sakasti.nsf/sp2?open\&cid=Content240FFA (accessed 15 May 2016). Thornberg R and Charmaz K (2012) Grounded theory. In: Lapan SD and Quartaroli MT and Riemer FJ (eds) Qualitative research: an introduction to methods and design. San Francisco: Jossey-Bass, pp.41-67.

Turner V (1969) The ritual process: Structure and anti-structure. New Jersey:

Transaction Publishers.

Turner V (1982) From ritual to theatre. The human seriousness of play. New York City: Performing Arts Journal Publications.

Turner V and Turner E (1982) Religious celebration. In: Turner V (ed) Celebration: studies in festivity and ritual. Washington: Smithsonian Institution Press, pp.201-219. Van Gennep A (1960) [1909] Rites of passage. London: Routledge.

Webber R (2012) Exploring volunteering of committed young Catholics. Journal of Beliefs \& Values 33(1): 71-82. 
Paula NISSILÄ is a doctoral student in the Faculty of Social Sciences (SOC) at University of Tampere, Finland. Her ongoing dissertation project in sociology focuses on the religious communality and festival meanings among youths at a Christian revivalist summer event. The project is carried out with the funding by the Kone Foundation. She is also a librarian, and has worked in the university library within information retrieval and scientific publishing. Address: 33014 University of Tampere, Finland Email: paula.nissila@uta.fi 